\title{
Quantitative estimation of aflatoxin level in broiler feed utilized in district Mansehra, Khyber Pakhtunkhwa, Pakistan
}

\author{
Muhammad Sohail $^{1 *}$, Naseem Bano ${ }^{1}$, Hamidullah ${ }^{1}$, Muhammad Sajid ${ }^{1}$, \\ Said Sajjad Ali Shah ${ }^{2}$, Muhammad Shoaib ${ }^{1}$ and Mehwish Malik ${ }^{1}$ \\ 1. Veterinary Research \& Disease Investigation Center Abbottabad Khyber Pakhtunkhwa-Pakistan \\ 2. Veterinary Research Institute Peshawar, Khyber Pakhtunkhwa-Pakistan \\ *Corresponding author's email: $\underline{\text { dr.msohail@ymail.com }}$ \\ Citation \\ Muhammad Sohail, Naseem Bano, Hamidullah, Muhammad Sajid, Said Sajjad Ali Shah, Muhammad Shoaib and \\ Mehwish Malik. Quantitative estimation of aflatoxin level in broiler feed utilized in district Mansehra, Khyber \\ Pakhtunkhwa, Pakistan. Pure and Applied Biology. Vol. 9, Issue 2, pp1576-1582.
}

http://dx.doi.org/10.19045/bspab.2020.90165

Received: 06/11/2019 Revised: 20/02/2020

Accepted: 16/03/2020

Online First: 18/03/2020

\section{Abstract}

Poultry feed with contaminated with mycotoxins especially aflatoxin is a major health concern. It directly results in significant economic losses and indirectly affects the health of consumers. District Mansehra (Hazara region) is rich in poultry population due to its favorable climate. No such study has been executed to estimate the Aflatoxin level in poultry feed in this area. So, the current study was conducted to educate the farmers regarding aflatoxin contamination at farm level. In this study, a total of 120 samples were collected from poultry feed supplied in Mansehra. Three different types of poultry feed were assessed viz; starter, grower and finisher feed and samples were collected from poultry farms of District Mansehra from 3 tehsils (Mansehra, Balakot \& Ogi) from March to July 2017. Enzyme-linked Immunosorbent Assay (ELISA) was used for screening of Total Aflatoxin (TA) in the samples. Overall, the incidence of positive samples for aflatoxin contamination was $92.5 \%$. The frequency of aflatoxin measured was highest in Tehsil Balakot i.e. $100 \%$, but higher levels were documented in Tehsil Mansehra viz; 54.6 ppb. Grower feed had the highest frequency of aflatoxin positive samples $(100 \%)$ as well as aflatoxin levels $(56.34 \mathrm{ppb})$. The moisture content was around 6.8-10.98\%. The association between total aflatoxin and moisture content was statistically significant $(\mathrm{P}<0.05)$. The results suggest that continuous monitoring regimes are required to be conducted to prevent aflatoxicosis in poultry birds.

Keywords: Aflatoxin; Broiler; ELISA; Feed; Humidity; Moisture

\section{Introduction}

Poultry industry in Pakistan is a vibrant segment of livestock sector with an annual growth rate $7.5-10 \%$ and its contribution in Gross Domestic Product (GDP) is $1.4 \%$ and value added to Agriculture and Livestock was $12.5 \%$ [1]. The demand of poultry eggs and meat is increasing day by day (4\% per annum). During the financial year 2017-18, 1.39 million tons of poultry meat was 
produced, which was $32.7 \%$ of total meat produced (4.3 million tons) in Pakistan [2]. District Mansehra is richly populated with commercial poultry farms due to its favorable climatic conditions. About 4 million broiler breeders, 2.5 million broilers, 0.5 million commercial layers and 3.00 million rural poultry are being reared in Hazara region [3]. Aflatoxins (AF) are major mycotoxins released by fungi (Aspergillus parasiticus \& Aspergillus flavus) which contaminate poultry feed ingredients and finished products [4]. The production of toxin can happen in both pre and post-harvest phases in crops. The aflatoxin B1 is one of the most lethal aflatoxin. It is important to analyze the aflatoxin level in feed or its ingredients before it is made available for feeding poultry birds/animals [5].

The aflatoxin (B1 \& B2) has been reported at varied levels in poultry feeds in Pakistan [6, 7]. Aflatoxicosis is immunosuppressant in broilers and also lowers the growth rate [8]. Moreover, its residues were found in liver and muscle cells [9]. Toxins in fungi/molds had directly and indirectly affected the safety of food products which resulted in loss to industry [10]. These toxins not only affect the bird's health but also the consumers health due to its deleterious effects AFB1 is one of the main naturally occurring carcinogen resulting toxicosis in poultry birds. International Agency for Research on Cancer (IARC) has classified AFB1 as group 1 carcinogen in humans [11]. Therefore, it's important to reduce the aflatoxin levels in poultry feeds in order to save the health of human beings [12].

Aflatoxins are considered as inevitable contaminants of food for which regulatory levels has been set by United States (US) Food and Drug Administration (FDA). The admissible level of aflatoxin in poultry feed is $20 \mathrm{ppb}[13,14]$.

It's worth mentioning that total aflatoxin levels in poultry feed disseminated in district
Mansehra has no data about aflatoxin levels. Hence, there is a dire need to estimate aflatoxin contamination quantitatively in feed supplied/utilized in various localities of Mansehra. The specific objectives set for the current survey were to conclude the level of aflatoxin in feed used for poultry birds and to study the climatic effect on aflatoxin occurrence and to make a comparison between various commercially available feeds.

\section{Materials and methods}

The sampling in the current study were carried out in district Mansehra and sample analyses were executed at Nutrition Lab at Veterinary Research and Disease Investigation Center Abbottabad. Detailed study was conducted for Quantitative Estimations of Total Aflatoxin level in poultry feed. The Aflatoxin level in poultry feed was estimated quantitatively in feed supplied in poultry farms of district Mansehra.

\section{Study area}

The current investigation was executed in three tehsils of district Mansehra viz; Mansehra, Balakot and Oghi as presented in the following map (Fig. 1).

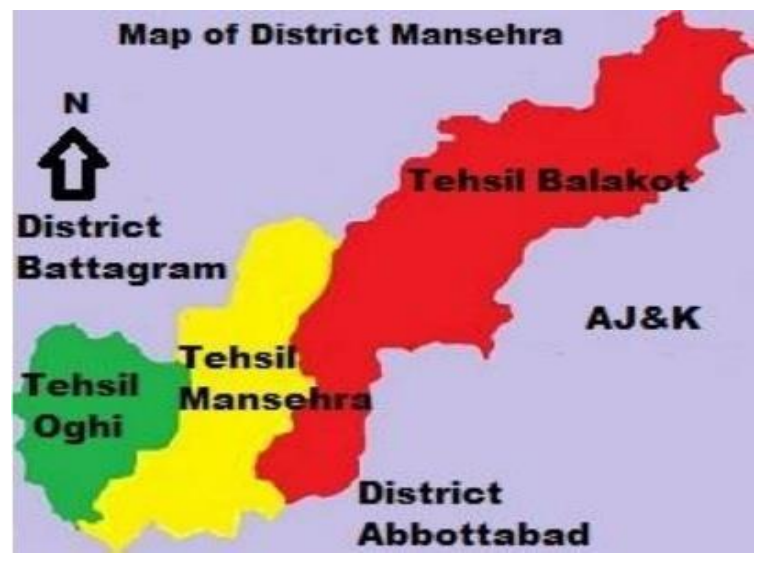

Figure 1. Map of district Mansehra

\section{Samples collection}

A total of 120 poultry feed samples $(n=40$ from each tehsil) were obtained at farm level from three tehsils. Three categories of feed 
samples were defined viz; Starter (1-19 days), Grower Crumbs (19-30 days) and Finisher Crumbs (31-50 days). Feed samples $(500 \mathrm{gm})$ were collected and stored in plastic bags sealed properly and shifted to Lab where samples were ground, homogenized and stored at $2-8^{\circ} \mathrm{C}$ for further analyses. The feed samples were collected randomly from various spots in the store rooms. The information regarding feed production was obtained on properly designed performa.

\section{Preparation of sample for extraction}

The feed samples were collectively and carefully prepared and mixed for extraction. About $5 \mathrm{gm}$ of feed sample was weighed and placed for four minutes in $25 \mathrm{ml}$ methanol (70\%) for extraction. Filter paper (Whatman) was used for filtration of the extract for further processing.

\section{Aflatoxin detection (Indirect-ELISA)}

The estimation of AFB1 in broiler feed samples was done by Direct Competitive ELISA, through Neogen Veratox ${ }^{\circledR}$ Aflatoxin Test Kit. The optical density (OD) was recorded immediately through ELISA reader (NEOGEN Microplate Reader model 6704 USA) at $650 \mathrm{~nm}$ filter and results were expressed in $\mu \mathrm{g} / \mathrm{kg}$.

\section{Moisture content calculation}

Standard protocols were used for determining moisture content in feed samples using hot air oven [15]. The samples were weighed before drying and reading was noted. Oven was set at $105^{\circ} \mathrm{C}$ for drying the samples. The left over samples were reweighed. The level of moisture considered safer for storage is 10$12 \%$ moisture contents [16].

$$
\begin{gathered}
\text { Dry factor } \%=\frac{W 2-W 1}{\text { Weight of sample }} \times 100 \\
\text { Moisture } \%=100-\text { Dryfactor }
\end{gathered}
$$

Whereas, $\mathrm{W}_{2}$ is post drying weight while $\mathrm{W}_{1}$ is empty crucible weight

\section{Results}

It was observed that the occurrence of Aflatoxin in broiler feed was very high. The detailed data is presented in the (Table 1).

The level of humidity observed was highest in Tehsil Balakot $(59.31 \%)$ followed by Tehsil Mansehra (57.64\%) and Tehsil Ogi
(55.51\%). In Tehsil Ogi, the mean level of total aflatoxin (TA) recorded in broiler feed samples were higher in grower feed $(49.5 \pm 1.86)$ followed by broiler finisher $(41.4 \pm 2.52)$ and starter feeds $(40.11 \pm 2.99)$. The mean moisture levels in feed samples (Starter, Grower and Finisher) from Tehsil Ogi were $7.4 \pm 0.27,8.3 \pm 0.27$ and $7.39 \pm 0.34$, respectively.

Table 1. Frequency of Total Aflatoxin level and moisture content in poultry feed with context

\begin{tabular}{|c|c|c|c|c|c|c|}
\hline Area & Feed type & $\begin{array}{c}\text { Aflatoxin (ppb) } \\
\text { Mean } \pm \text { SE }\end{array}$ & $\begin{array}{l}\text { Moisture content } \\
(\%) \text { Mean } \pm \text { SE }\end{array}$ & $\begin{array}{c}\mathrm{P} \\
\text { value }\end{array}$ & $\begin{array}{l}\text { Humidity } \\
\text { level }(\%)\end{array}$ & $\begin{array}{c}\mathrm{P} \\
\text { value }\end{array}$ \\
\hline \multirow{3}{*}{ Ogi } & Broiler starter & $40.11 \pm 2.99$ & $7.4 \pm 0.27$ & \multirow{9}{*}{0.00} & \multirow{3}{*}{55.51} & \multirow{9}{*}{0.00} \\
\hline & Broiler grower & $49.5 \pm 1.86$ & $8.3 \pm 0.27$ & & & \\
\hline & Broiler Finisher & $41.4 \pm 2.52$ & $7.39 \pm 0.34$ & & & \\
\hline \multirow{3}{*}{ Balakot } & Broiler starter & $58.5 \pm 2.7$ & $9.5 \pm 0.16$ & & \multirow{3}{*}{59.31} & \\
\hline & Broiler grower & $64.6 \pm 2.5$ & $9.7 \pm 0.2$ & & & \\
\hline & Broiler Finisher & $67.3 \pm 2.97$ & $9.7 \pm 0.2$ & & & \\
\hline \multirow{3}{*}{ Mansehra } & Broiler starter & $46.4 \pm 2.34$ & $7.9 \pm 0.19$ & & \multirow{3}{*}{57.64} & \\
\hline & Broiler grower & $58.2 \pm 1.86$ & $8.8 \pm 0.21$ & & & \\
\hline & Broiler Finisher & $52.3 \pm 2.96$ & $8.3 \pm 0.1$ & & & \\
\hline
\end{tabular}
to relative humidity in different Tehsils of district Mansehra 
In Tehsil Balakot, the mean level of total aflatoxin (TA) recorded in broiler feed samples was highest in finisher feed $(67.3 \pm 2.97)$ followed by broiler grower $(64.6 \pm 2.5)$ and starter feeds (58.5 \pm 2.7$)$ whereas the mean moisture contents of feed samples (Starter, Grower and Finisher) were $9.5 \pm 0.16,9.7 \pm 0.2$ and $9.7 \pm 0.2$, respectively. In Tehsil Mansehra, the mean level of total aflatoxin (TA) recorded in broiler feed samples was higher in Grower Feeds $(58.2 \pm 1.86)$ followed by finisher $(52.3 \pm 2.96)$ and grower feeds $(46.4 \pm 2.34)$ whereas the mean moisture contents in feed samples (Starter, Grower and Finisher) were $7.9 \pm 0.19, \quad 8.8 \pm 0.21$ and $8.3 \pm 0.1$, respectively.

It was observed that the aflatoxin level in feed samples were highest from Tehsil Balakot followed by Tehsil Mansehra and lastly Tehsil Ogi. Similarly, the moisture level in feed samples was also related to relative humidity of these areas. Moisture levels were higher in feed samples from Balakot followed by Mansehra and tehsil Ogi. The incidence of TA occurrence was highly significant $(\mathrm{P}<0.05)$ in all three broiler feeds viz; starter, grower and finisher. Similarly, the effect of humidity level on moisture contents in feed and TA presence in feed was also highly significant i.e. $\mathrm{P}<0.05$. .The TA levels were highest in finisher feeds from Balakot followed by Grower and finisher feeds.

A direct relation was observed between aflatoxin level (ppb) and moisture content of feed (\%) in scatter plot (Fig. 2). The aflatoxin level has increased with increase in the level of moisture contents in broiler feeds. The minimum level of TA noticed was $20.90 \mathrm{ppb}$ while the highest value was $86.20 \mathrm{ppb}$.

Box and Whisker plot shows that the inter quartile range (IQR) for starter feed was 13 in Balakot, 11 in Mansehra and 12 in tehsil Ogi. For grower feed, the IQR was 8, 10 and 13 in Balakot, Mansehra and tehsil Ogi, respectively. Similarly, the IQR was 19 for finisher feed in tehsil Balakot while 9 each in teshil Mansehra and Ogi. The median in tehsil Ogi was 40.11, 49.5 and $41.4 \mathrm{ppb}$ for starter, grower and finisher feed, respectively. Similarly, in Balakot median was $58.5,64.6$ and $67.3 \mathrm{ppb}$ for starter, grower and finisher feed, While in Mansehra tehsil aflatoxin median recorded was 46.4 , 58.2 and $52.3 \mathrm{ppb}$ for starter, grower and finisher feed. (Fig. 3).

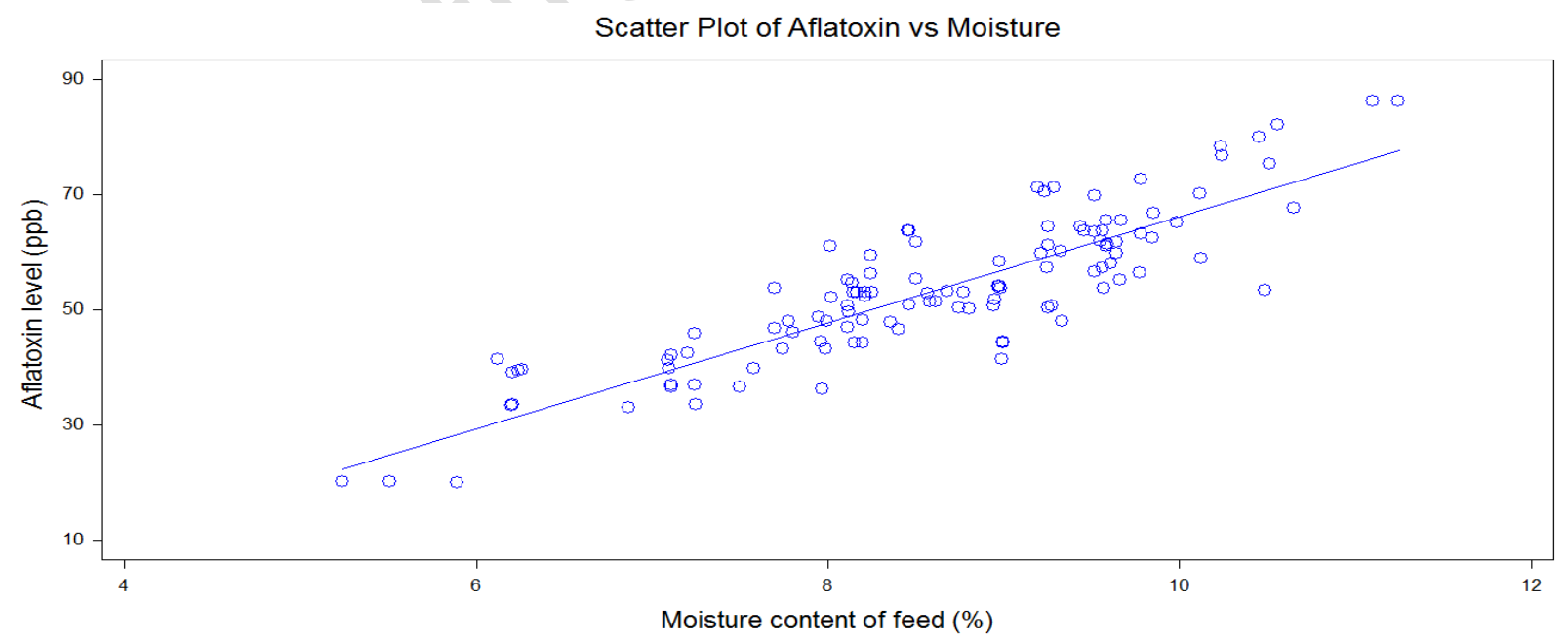

Figure 2. Scatter plot showing aflatoxin level (ppb) against moisture content (\%) of feed 


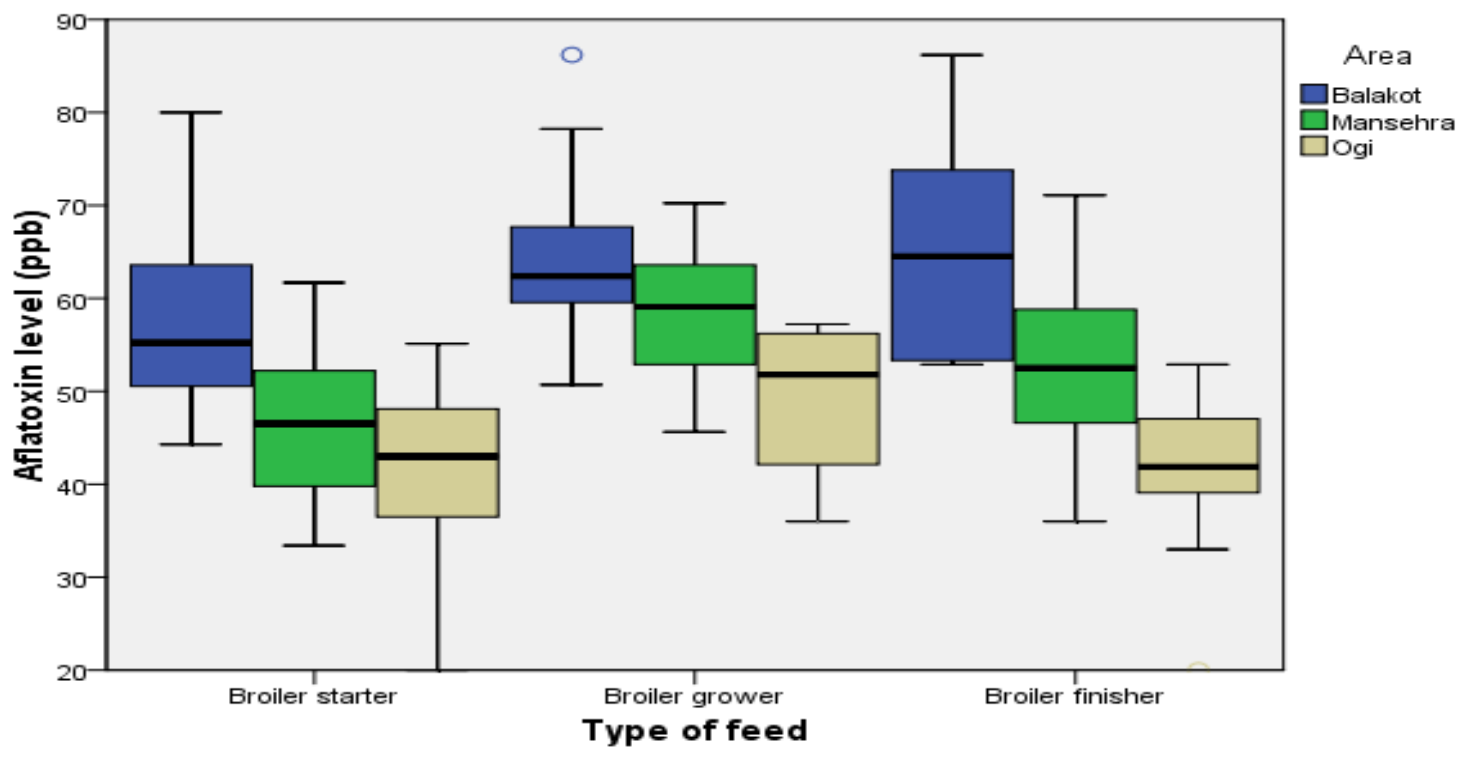

Figure 3. Box and whisker plot showing aflatoxin level (ppb) in different type of poultry feed in district Mansehra

\section{Discussion}

Poultry feed is being naturally contaminated by toxic fungal metabolites (aflatoxin). The major fungal species which are responsible for this contamination are Aspergillus flavus and Aspergillus fumigatus [17]. The growth of molds and their toxin production is optimal in humid conditions with high temperatures [18].

As depicted in the results of this study, the total aflatoxin level were higher than permissible limits in almost $97 \%$ of broiler feed samples. The minimum level of TA noticed was $20.90 \mathrm{ppb}$ while the highest value was $86.20 \mathrm{ppb}$. It was noted that most of the farmers has no awareness about storage at farms. There were no airing; proper loading, abundance of insects, rodents were found and feed stores were humid. This resulted in higher total aflatoxin levels as observed in this study. Globally, a varied level of aflatoxins has been reported in various studies. In Brazil, about $88.2 \%$ feed samples were found positive for aflatoxin through competitive ELISA which supports the findings of current study [19]. Similarly, commercially available feed ingredients used in formulation of poultry feed were analyzed in a study in Pakistan which showed elevated aflatoxin level [6]. In Morocco, aflatoxin contamination in poultry feed was studied and reported that $66.6 \%$ of feed samples were contaminated [20]. In India and Bangladesh, a high level of aflatoxin was reported in a study which supports the findings of current study. In India it was $>10 \mathrm{ppb}$ while in Bangladesh aflatoxin level was 7 to160 ppb [21].

Results of current study showed that feed supplied in Tehsil Balakot has higher aflatoxin level. These findings are supported by a study which recorded higher aflatoxins in feed ingredients stored at high temperature [22]. The moisture levels in tehsil Balakot are higher when compared with other Tehsils; Mansehra and Ogi which is an important factor in growth of moulds and development of Aflatoxins.

The level of TA was highest in broiler finisher feed and lowest in broiler starter 
feeds. However, it was above the permissible limits for poultry in almost 97\% of feed samples. In a study conducted on broiler starter feed which showed an elevated level of aflatoxin i.e. 100 to $320 \mu \mathrm{g} / \mathrm{Kg}$ [6].

It was reported in various studies that increased aflatoxin levels were noticed in feeds with elevated moisture contents which shows a direct relation between the moisture content and occurrence of Total aflatoxin levels [23]. In feed samples from tehsil Balakot, the moisture levels were higher and TA levels were also higher than other areas of the study. Several factors such as climatic conditions [24] and storage conditions, like high temperature and humidity are optimal for the growth of moulds and affect fungal colonization and mycotoxin production in grains and compound feeds [25]. The excessive growth of fungus ultimately results in elevation of aflatoxin in feed stuffs and compound feeds.

\section{Conclusion}

The findings of this study show that the farmers of the study area do not have sufficient knowledge regarding feed storage which results in feed deterioration and aflatoxin production. Such higher toxin levels not only reduce the production capacity of the bird but also are a threat to human health and increase the economic losses to the farmers.

\section{Authors' contributions}

Conceived and designed the experiments: $\mathrm{M}$ Sohail \& N Bano, Performed the experiments: M Sajid, N Bano \& M Shoaib, Analyzed the data: SSA Shah, M Malik \& M Sohail, Contributed materials/ analysis/ tools: Hamidullah, Wrote the paper: M Sohail \& SSA Shah.

\section{References}

1. Pakistan Economic Survey (2017-2018). GoP, Minist. Natl Food Secur Res, pp 27.
2. Agriculture Statistics of Pakistan (20172018). Estimated meat and egg production 2018. Islamabad, pp 29.

3. Malik M, Sohail M, Sajid M, Hamidullah, Bibi F \& Shoaib M (2019). Seroprevalence of Mycoplasma Gallisepticum in non-vaccinated broiler flocks in Abbottabad Khyber Pakhtunkhwa, Pakistan. Res in Agri \& Vet Sci 3: 36-42.

4. Sherazi STH, Shar ZH, Bhanger MI, Sumbal GA \& Nizamani SM (2013). Economical appraisal of total aflatoxin level in the poultry feeds by fourier transform infrared spectroscopy. J Pak Chem Soc 35: 363-368.

5. Reddy K, Reddy C \& Muralidharan K (2009). Detection of Aspergillus spp. and aflatoxin B1 in rice in India. Food Micro 26: 27-31.

6. Anjum M, Sahota A, Akram M \& Ali I (2011). Prevalence of mycotoxins in poultry feeds and feed ingredients in Punjab (Pakistan). J of Anim Plant Sci 2: 117-120.

7. Rashid N, Bajwa M, Rafeeq M, Khan M, Ahmad Z, Tariq M, Wadood A \& Abbas $F$ (2012). Prevalence of aflatoxin B1 in finished commercial broiler feed from west central Pakistan. J Anim Plant Sci 22: 6-10.

8. Verma J, Johri T, Swain B \& Ameena S (2004). Effect of graded levels of aflatoxin, ochratoxin and their combinations on the performance and immune response of broilers. Brit Poult Sci 45: 512-518.

9. Bintvihok A, Thiengnin S, Doi K \& Kumagai S (2002). Residues of aflatoxins in the liver, muscle and eggs of domestic fowls. J of Vet Medi Sci 64: 1037-1039.

10. Saeed M, Ahmad I, Sakhawat A, Ashraf M, Khurram S, Haq I \& Shaikh M (2009). Comparative evaluation of sorbatox and bentonite for detoxification 
of aflatoxin contaminated layer feed. Pak J Food Sci 19: 27-31.

11. Kamika I \& Takoy LL (2011). Natural occurrence of Aflatoxin B1 in peanut collected from Kinshasa, Democratic Republic of Congo. Food Control 22: 1760-1764.

12. Alshawabkeh $\mathrm{K}$, Alkhalaileh $\mathrm{N}$, Abdelqader A, Al-Fataftah ARA \& Herzallah SM (2015). Occurrence of aflatoxin B1 in poultry feed and feed ingredients in Jordan using ELISA and HPLC. American-Eurasian $J$ of Toxicological Sci 7: 316-320.

13. United States Food and Drug Administration. Guidance for Industry: Action Levels for Poisonous or Deleterious Substances in Human Food and Animal Feed. United States Food and Drug Administration; Silver Spring, MD, USA: 2000.

14. FAO. Worldwide Regulations for Mycotoxins in Food and Feed in 2003. Rome: Food and Nutrition Papers, Food and Agriculture Organization of the United Nations; 2004.

15. Akiyama $\mathrm{H}$, Goda $\mathrm{Y}$, Tanaka $\mathrm{T} \&$ Toyoda M (2001). Determination of aflatoxins B1, B2, G1 and G2 in spices using a multifunctional column clean-up. J of Chromatogr A 932(1-2): 153-157.

16. Joffe A \& Lisker $N$ (1969). Effects of light, temperature, and $\mathrm{pH}$ value on aflatoxin production in vitro. Appl Micro 18: 517-518.

17. Ali N, Hashim N, Saad B, Safan K, Nakajima M \& Yoshizaw T (2005). Evaluation of a method to determine the natural occurrence of aflatoxins in commercial traditional herbal medicines from Malaysia and Indonesia. Food and Chemical Toxicol 43: 1763-1772.

18. Ventura M, Gómez A, Anaya I, Díaz J, Broto F, Agut M \& Comellas L (2004).
Determination of aflatoxins B1, G1, B2 and $\mathrm{G} 2$ in medicinal herbs by liquid chromatography-tandem mass spectrometry. J of Chromatogr A 1048: 25-29.

19. Rossi CN, Takabayashi CR, Ono MA, Saito GH, Itano EN, Kawamura O, Hirooka EY \& Ono EYS (2012). Immunoassay based on monoclonal antibody for aflatoxin detection in poultry feed. Food Chem 132: 22112216.

20. Zinedine A, Juan C Soriano J, Molto J, Idrissi L \& Manes J (2007). Limited survey for the occurrence of aflatoxins in cereals and poultry feeds from Rabat, Morocco. Int J of Food Micro 115: 124127.

21. Dawlatana M, Coker R, Nagler M, Wild C, Hassan M \& Blunden G (2002). The occurrence of mycotoxins in key commodities in Bangladesh: surveillance results from 1993 to $1995 . J$ of Natural Toxins 11: 379-386.

22. Cavalheiro AC (1981). Aflatoxin and Aflatoxicosis-A Review. World's Poult Sci J 37: 34-38.

23. Fareed G, Anjum MA \& Ahmed N (2014). Determination of Aflatoxin and Ochratoxin in poultry feed ingredients and finished feed in humid semi-tropical environment. $J$ of Adv Vet \& Ani Res 1: 201-207.

24. Dersjant-Li Y, Verstegen MWA \& Gerrits WJJ (2003). The impact of low concentrations of aflatoxin, deoxynivalenol or fumonisin in diets on growing pigs and poultry. Nutr Res Rev 16: 223-239.

25. Rawal S, Kim JE \& Coulombe Jr. R (2010).Aflatoxin B1 in poultry: toxicology, metabolism and prevention. Res Vet Sci 89: 325-331. 